\title{
Marsjanie. Borowczyk i Lenica na Międzynarodowym Konkursie Filmu Eksperymentalnego w Brukseli
}

\author{
PAWEŁ SITKIEWICZ \\ Uniwersytet Gdański
}

\begin{abstract}
Aвstract. Sitkiewicz Paweł, Marsjanie. Borowczyk i Lenica na Międzynarodowym Konkursie Filmu Eksperymentalnego w Brukseli [Martians. Borowczyk and Lenica on International Experimental Film Competition in Brussels]. "Images" vol. XXVII, no. 36. Poznań 2020. Adam Mickiewicz University Press. Pp. 289-301. ISSN 1731-450X. DOI 10.14746/i.2020.36.18.

The text describes the backstage of the legendary International Experimental Film Competition in Brussels, which accompanied the Expo-58 Exhibition at a turning point of the political thaw in Eastern and Central Europe. The most important representatives of avant-garde cinema and auteur animation of three generations took part in this event. The Grand Prix was awarded to The House of Walerian Borowczyk and Jan Lenica. The prize became the ticket to a European career for these two young filmmakers. The competition was also remembered as a symbolic beginning of the "Polish school of animation" (or the so-called "Polish school of experimental film") on the global film market. The author of the article also writes about a difficult return to Poland, about a cash prize that caused many problems, about the successes of Polish films in Brussels, and about the reception of The House in Poland and abroad. Finally, he tries to demonstrate why this bleak and difficult to understand film, which builds opposition to the optimism of Expo Exhibitions, won the main prize, beating over 300 competitors from around the world.
\end{abstract}

KEYwORDS: animated film, experimental film, Jan Lenica, Walerian Borowczyk, The House, Polish School of Animation, Expo-58 in Brussels

„Borowczyk i Lenica wstali, i nagle, spontanicznie padli sobie $\mathrm{w}$ ramiona, i ucałowali się z dubeltówki. Przewodniczący jury w Wielkim Audytorium Wystawy w Brukseli uspokajał publiczność" [1]. Piszący te słowa Jan Gerhard, korespondent polskiej prasy, próbował przedrzeć się w tłumie do laureatów, by złożyć im gratulacje. Na próżno. Byli oblegani ze wszystkich stron. To przełomowy moment w karierze Jana Lenicy i Waleriana Borowczyka - dwóch młodych grafików i animatorów z Warszawy. Ich Dom wygrał Międzynarodowy Konkurs Filmu Eksperymentalnego, który zorganizowano przy okazji wystawy światowej Expo-58 w Brukseli. Choć nie uchodzili za faworytów, pokonali 403 filmy z całego świata. W uzasadnieniu jury napisało: „Ten film stanowi próbę spożytkowania wrodzonych możliwości sztuki kinematograficznej, która jest sztuką czysto wizualną" [2].
W audytorium rozbrzmiewają brawa, ale również gwizdy i buczenie. Werdykt budzi kontrowersje. "Jakaś grupa posługująca się językiem angielskim [...] protestowała, ale ich słowa utonęły w ogólnym aplauzie" [3]. Zdaniem Gerharda buczeli Amerykanie, którzy do Brukseli przylecieli z największym zestawem filmów i liczyli na Grand Prix.

Jeszcze tego samego dnia odbyły się projekcje nagrodzonych tytułów. Do Lenicy i Bo-

[1] J. Gerhard, Sukces polskich filmów eksperymentalnych w Brukseli, „Przekrój” 1958, nr 685, s. 19-20.

[2] R. Onckelinx, Days of experiment, „Films and Filming", June 1958, s. 10. Wszystkie tłumaczenia są mojego autorstwa.

[3] J. Gerhard, Po międzynarodowym Konkursie Filmów Eksperymentalnych, „Wiadomości Filmowe" 1958 , nr 22, s. 4. Następny cytat za tym samym źródłem. 
rowczyka podchodzili reżyserzy, producenci, dziennikarze i oficjele z całego świata. Jedni chcieli uścisnąć dłoń, drudzy - złożyć propozycję współpracy. „Wszyscy mówili właściwie jedno i to samo: "Wasze polskie filmy są jakieś inne... Pełne wymowy. Wywierają głębokie wrażenie»".

„Wierzyliśmy w Dom i jesteśmy do tego filmu bardzo przywiązani, trudno się nam jednak jeszcze otrząsnąć z oszołomienia wywołanego otrzymaniem pierwszej nagrody [...]"[4] - powiedzieli Lenica i Borowczyk polskiemu korespondentowi. Planowali wrócić do Polski, by "tworzyć dalej filmy eksperymentalne, jeszcze lepsze i jeszcze celniejsze niż Dom”. Ich losy potoczyły się inaczej. To ich ostatni wspólny film, a zarazem początek dwóch niezależnych karier w kinie europejskim. A jednocześnie: symboliczny początek polskiej szkoły animacji na arenie międzynarodowej.

\section{Konkurs Polaków}

Brukselski konkurs uchodzi za jedno z najbardziej legendarnych wydarzeń w historii kina eksperymentalnego. Krótko po jego zakończeniu Lewis Jacobs pisał na łamach „Film Culture”: „był to rodzaj filmu zamkniętego $\mathrm{w}$ ciemnej piwnicy $\mathrm{w}$ prawie każdym kraju na świecie, zanim 27 kwietnia 1958 roku nie wywołano go na światło dzienne powszechnego uznania. Tego dnia pierwsze wibracje nowej ery twórczości filmowej zostały oficjalnie odnotowane"[5]. Publiczność czekała na objawienie nowego sposobu obrazowania lęków i wyzwań „epoki atomu” językiem awangardy filmowej. W konkursie brali udział wszyscy liczący się twórcy kina eksperymentalnego oraz animacji autorskiej. Co więcej, ich rywalizacja - a zarazem konfrontacja stylów i technik - odbywała

[4] Idem, Walerian Borowczyk i Jan Lenica po sukcesie „Domu” w Międzynarodowym Konkursie Filmów Eksperymentalnych, „Wiadomości Filmowe" 1958 , nr 23.

[5] L. Jacobs, Morning for the experimental film, „Film Culture” 1959, No. 19, s. 8.

[6] M. Hendrykowski, Dwaj ludzie z szafa. Historia pewnej etiudy, Poznań 2015, s. 117. się w świetle jupiterów, ponieważ towarzyszyła imprezie, którą śledziły media na całym świecie i którą odwiedziły miliony widzów.

„Należy pamiętać - pisze Marek Hendrykowski - iż impreza ta, mająca $\mathrm{z}$ założenia globalny zasięg, odbywała się jednak w szczególnych warunkach konfrontacji dwóch światów - wówczas od parunastu lat podzielonych ideologicznie zimną wojną" [6]. Na wystawie światowej, podobnie jak na konkursach filmowych, prezentowały się kraje bloku wschodniego. Pawilon sowiecki oblegały tłumy. Zachód ciekaw był, jak wygląda życie za żelazną kurtyną po odwilży politycznej oraz jaki wizerunek zaprezentuje ZSRR.

Nie była to pierwsza edycja konkursu. Wcześniejszą wygrał przebywający na emigracji w Stanach Zjednoczonych Niemiec Oskar Fischinger za film Motion Painting No. 1 (1947), zaliczany dziś do klasyki animacji abstrakcyjnej. Różnica polega na tym, że w roku 1949 zwycięzcom wręczono dyplomy, a werdykt przeszedł niemal bez echa. W 1958 roku pula nagród wyniosła kilkadziesiąt tysięcy dolarów, a o konkursie pisały wysokonakładowe dzienniki.

W jury zasiadły same znakomitości: Alexandre Alexeieff - rosyjsko-francuski pionier animacji autorskiej, który we współpracy z Claire Parker realizował filmy z pomocą tak zwanego ekranu szpilkowego; John Grierson - szkocki dokumentalista, jeden ze współtwórców słynącej ze społecznego zaangażowania brytyjskiej szkoły dokumentu; Pierre Prévert - francuski reżyser filmowy; Curt Oertel - niemiecki operator i reżyser, autor zdjęć do między innymi Zatraconej uliczki G.W. Pabsta; Man Ray - amerykański artysta plastyk, fotograf i filmowiec; Edgar Varèse - francusko-amerykański kompozytor awangardowy, jeden z ojców muzyki elektronicznej; Pierre Vermeylen - belgijski polityk, między innymi minister spraw zewnętrznych i prezydent Cinémathèque Royale de Belgique; Norman McLaren - szkocki animator pracujący dla National Film Board of Canada, który uchodził za światowego lidera animacji niezależnej.

Do konkursu zgłoszono 403 filmy, z których wyselekcjonowano 137, w tym aż 7 z Polski, 57 ze 
Stanów Zjednoczonych, 17 z Francji, 12 z Anglii, 9 z NRF, 6 ze Szwecji i 6 z Belgii. Większość krajów, nawet takich jak Japonia czy Jugosławia, reprezentowała tylko jeden tytuł. Co ciekawe, w finale nie znalazł się żaden film ze Związku Radzieckiego, dlatego ambasadorem bloku wschodniego została Polska.

W konkursie brali udział między innymi: Stan Brakhage, Agnes Varda, John Whitney, Abel Gance, Len Lye, Peter Kubelka, John Hubley, Robert Breer, Jonas Mekas, Georges Franju, Jean Mitry, Maya Deren, Ken Russell. Na jednej imprezie spotkali się twórcy, których nazwiska wyznaczają kamienie milowe w historii kina eksperymentalnego trzech pokolen. Skala profesjonalizmu wahała się od amatorskich wprawek na taśmie $16 \mathrm{~mm}$ po superprodukcje na poliekranie z dźwiękiem stereofonicznym. Równie szeroka była skala rodzajowa i gatunkowa: od utrzymanych w poetyce limited animation kreskówek wytwórni United Productions of America, przez rozmaite poetyckie lub niekonwencjonalne odmiany kina fabularnego i dokumentalne impresje, po całe bogactwo awangardy i autorskie filmy animowane.

Polskę reprezentowali: surrealistyczny Dom Borowczyka i Lenicy, poetycka fabuła Dwaj ludzie z szafa Romana Polańskiego, dwa obrazy abstrakcyjne: Kineformy Andrzeja Pawłowskiego oraz Somnambulicy Mieczysława Waśkowskiego, dwa dokumenty: Życie jest piękne Tadeusza Makarczyńskiego oraz Warszawa 1956 Jerzego Bossaka i Jarosława Brzozowskiego, a także - jak podaje Gerhard - amatorski film Perdu Rostandrego, o którym nic nie wiadomo[7].

Film eksperymentalny mógł wydawać się w powojennej Polsce zjawiskiem obcym, zwłaszcza że krajowe środowisko artystyczne przez długie lata było odcięte od nowinek światowej awangardy[8]. Krótko mówiąc, istniała obawa, że polski zestaw wyda się albo anachroniczny, albo zbyt osobny. Z drugiej strony, istnieją dowody, że w gronie znawców po cichu liczono na sukces. Antoni Bohdziewicz w listopadzie 1957 roku pisał w liście do Lenicy i Borowczyka, którzy szukali mecenasa dla nowego projektu: „Mimo wszystko - TRZEBA COŚ POSŁAĆ DO BRUKSELI i Wy jesteście najbardziej do tego powołani”[9]. Dlatego otrzymali wsparcie finansowe i w ekspresowym tempie (niecały miesiąc!), omijając wszelkie pułapki decyzyjne, zrealizowali Dom dla „Kadru” Jerzego Kawalerowicza.

Filmy konkursowe wyświetlano w czternastu sesjach, po trzy projekcje dziennie otwarte dla publiczności, która miała do dyspozycji małe audytorium na 500 osób. Maraton rozpoczęła spektakularna Magirama Abla Gance’a, wyświetlana na poliekranie[10]. Jak pisał Karel Reisz w sprawozdaniu z imprezy, faworytem komisji selekcyjnej był podobno Stan Brakhage, który wprowadził do finału aż sześć filmów, między innymi Anticipation of the Night i Loving[11].

Już w trakcie konkursu pojawiły się głosy, że polskie filmy mogą liczyć na nagrody. Przyjmowano je entuzjastycznie, uchodziły za czarnego konia tej rywalizacji[12]. Najwięcej nadziei budziła etiuda Romana Polańskiego o dwóch ludziach z szafą, którzy zmagają się z ludzką głupotą oraz agresją wobec wszystkiego, co inne. Jako rewelacja konkursu, a zarazem niespodzianka (nikt przecież nie kojarzył nazwiska studenta łódzkiej „filmówki”), był bodaj najdłużej oklaskiwanym filmem[13]. Odnoszę wrażenie, że właśnie na takie filmy czekała za-

[7] (G) [J. Gerhard], Siedem filmów polskich zakwalifikowanych do konkursu, „Wiadomości Filmowe" 1958, nr 20, s. 5.

[8] Por. J. Płażewski, Grand Prix w Brukseli, „Życie Warszawy" 1958, nr 102.

[9] List A. Bohdziewicza do W. Borowczyka i J. Lenicy, 12.11.1957, Cinématheque Française, zbiory Waleriana Borowczyka. Dziękuję dr. Kubie Mikurdzie za udostępnienie materiałów z CF. [10] R. Onckelinx, op.cit.

[11] K. Reisz, Experiment at Brussels, „Sight and Sound" 1958, vol. 27, no. 5, s. 232.

[12] Sukces polskich filmów eksperymentalnych na konkursie w Brukseli, „Trybuna Ludu” 1958, nr 113. [13] Zob. K. Reisz, op.cit.; Le film polonais DOM remporte le Premier Grand Prix de la Compétition Internationale du Film Expérimental, „La nouvelle gazette", 30 kwietnia 1958. 
równo widownia, jak i jury: ciekawe formalnie, ale zrozumiałe, zaangażowane w problemy współczesnego świata, lecz zarazem poetyckie i niejednoznaczne. Dla Jonathana Hakera Dwaj ludzie $z$ szafa to zaprzeczenie typowego filmu eksperymentalnego, który zazwyczaj jest „długi, zagmatwany, nieprzejrzysty, nieproporcjonalny, pozbawiony poczucia humoru i technicznie nieudolny"[14]. Etiuda Polańskiego jest zaś zabawna, dobrze skonstruowana i czytelna.

Niespodziewanie wygrał Dom. Mroczny, enigmatyczny, pozbawiony poetyckiego uroku Dwóch ludzi z szafa. W dużym zarysie: składa się on z sześciu luźnych sekwencji oraz refrenu - widoku kobiety, która odgrywa rolę obserwatora. Film rozpoczyna się i kończy obrazem mrocznej kamienicy, nad którą przemyka lub pulsuje tajemniczy obiekt. Każda ze scen uruchamia w widzu inne skojarzenia. Sztuczna inteligencja kreuje nowe byty i ulega własnej niemocy. Dwie postacie z chronofotografii Mareya toczą pojedynek. Mężczyzna wchodzi do pokoju i odkłada kapelusz na wieszaku - a cała sekwencja powtarza się kilkukrotnie. Żywa peruka zjada owoce, wypija mleko i robi bałagan. Naga kobieta wspomina obce miejsca, podróże i dawne czasy. Ligia Borowczyk całuje głowę manekina, która rozpada się na kawałki. Film ilustrują złowrogie efekty akustyczne autorstwa Włodzimierza Kotońskiego.

Oprócz drugiej nagrody, która trafiła do Lena Lye’a ze Stanów Zjednoczonych za Free Radicals, jury postanowiło ufundować sześć równorzędnych nagród trzecich dla Yorama Grossa (Izrael), Romana Polańskiego (Polska), Hy Hirsha (Stany Zjednoczone), Hillary'ego

[14] J. Haker, Two Men and a Wardrobe, „Film Quarterly", Spring 1959, vol. 12, no. 3, s. 55.

[15] Le film polonais...; M.J., Soirée de clôture de la compétition internationale en film expérimental, „La derniere heure”, 29 kwietnia 1958. Jeżeli nie jest zaznaczone inaczej, szczegóły na temat gali wręczenia nagród podaję za tymi dwiema obszernymi relacjami prasowymi.

[16] P. Tyler, New Images, „Film Quarterly”, Spring 1959, vol. 12, no. 3, s. 51.

[17] K. Reisz, op.cit., s. 233.
Harrisa (Stany Zjednoczone), Francisa Thompsona (Stany Zjednoczone) i Rodolfa Kuhna (Argentyna). Nagrodami dodatkowymi zostały uhonorowane filmy Agnes Vardy (nagroda Federation Internationel des Cines-Clubs), Stana Brakhage’a (nagroda jury za zestaw filmów) i Kennetha Angera (Le prix de l'Age d'Or).

Amerykanie faktycznie mogli się czuć rozczarowani. Do domu zabrali aż siedem wyróżnień z jedenastu. Do pełni chwały brakowało im tylko Grand Prix, które trafiło w ręce dwóch egzotycznych Polaków.

Zwyciężył film odważny, w pełni profesjonalny: zrealizowany na barwnej taśmie $35 \mathrm{~mm}$, $\mathrm{z}$ muzyką nagraną $\mathrm{w}$ studiu i zawodową aktorką w roli głównej, sfinansowany - co okaże się istotne $-\mathrm{z}$ publicznych środków. Nie tylko odwoływał się do tradycji Wielkiej Awangardy, ale również wychodził przed szereg artystycznych poszukiwań tamtej epoki. Przede wszystkim: wygrał zgodną decyzją jurorów. W trakcie oficjalnych przemówień po ogłoszeniu nagród Pierre Vermeylen wyjaśnił, że zadanie jury było trudne, gdyż zwycięski film musiał otrzymać przynajmniej pięć głosów na siedem[15]. Wyłonienie Grand Prix zajęło aż dwanaście godzin.

Nawiązania do surrealizmu i tradycji filmu wizyjnego szczęśliwie zostały w Brukseli odczytane. Jury dostrzegło, że Dom to kino „czysto wizualne" i poetyckie, a nie anegdotyczne. Parker Tyler pisał na łamach „Film Quarterly”:

Kapitał, który wyróżnia Dom, z tych lub innych powodów poważnie zaniedbano w dużej większości filmów oglądanych na Festiwalu, a to właśnie on mógł przyczynić się do zdobycia Grand Prix. Jest nim oszczędna, zmysłowo piękna powierzchnia: równomiernie zaprojektowana i czarująca wizja, której czysta, dramatyczna kompozycja nigdy nie szwankuje[16].

Karel Reisz komplementował zaś w „Sight and Sound": „Jego odkrywczość jest świeża, zawartość obrazów - nieprzerwanie fascynująca, sposób uchwycenia medium - solidny; działa intensywnie i z dużym stężeniem poezji" [17].

Komentatorzy docenili odwage polskich twórców, którzy nie ulegli modom (gdyż ich nie znali), nie próbowali przypodobać się wi- 
downi ani jury (gdyż nie chcieli). Dom - pisał francuski dziennikarz Claude de Givray - miał „tę ogromną zaletę, że nie był naznaczony żadną szkołą. Godził, powiedzmy, punkty widzenia Pierre'a Preverta i McLarena. Znakiem odwagi tego delikatnie surrealistycznego dziełka jest żarłoczna peruka, która tłucze szklankę, drze papier, pożera pomarańczę i kradnie butelkę mleka"[18].

Równie atrakcyjni musieli wydawać się autorzy filmu. Pewni siebie, elokwentni, zadziorni, a jednocześnie introwertyczni i tajemniczy. Przekonani, że kino, które tworzą, wyznacza nowe kierunki dla europejskiej awangardy. Derek Hill wspominał, że w trakcie konkursu, prawdopodobnie już po wręczeniu nagród, odbyła się dyskusja na temat zwycięskiego filmu, w trakcie której ktoś zauważył, że wygląda on tak, jakby został zrealizowany na Marsie. Borowczyk odparował: „Ja jestem z Marsa”[19].

Ta anegdota dobrze oddaje aurę, która otaczała polskich autorów. W konkursie brało udział przeszło sto filmów, ale większość z nich zgodna była z oczekiwaniami. Albo powielała przedwojenne wzorce, albo odwoływała się do modnych trendów w kinie eksperymentalnym tamtych czasów. A jury czekało na film z Marsa.

Dominowała abstrakcja. „W ciągu całego konkursu filmy nawet najbardziej abstrakcyjne, w których tylko występował człowiek, brały górę nad tymi, w jakich była mowa o przedmiotach martwych, barwach czy kształtach" [20] zauważył Gerhard, a wtórował mu drugi polski korespondent, Jerzy Płażewski:

\footnotetext{
Dużą niespodzianką był dla mnie fakt, że nawet wysnobowana i łasa na formalne nowinki publiczność brukselska niechętnie odbiera abstrakcję. Ani walka plam barwnych, ani harmonijny rozwój linii, ani transmutacje literowe, ani balet form geometrycznych, choćby najbardziej wymyślnych, nie zapalały publiczności[21].
}

Tak samo uważał John Grierson. Po ogłoszeniu werdyktu mówił: „Jestem tylko trochę rozczarowany tym, że zbyt wiele uwagi poświęcono doskonałości technicznej, a za mało duchowi - duszy przedstawionych problemów"[22]. A tego akurat nie można zarzucić
Borowczykowi i Lenicy. W Brukseli wymusili interpretację swojego filmu: „Obrazy, które rzuciliśmy na ekran, wyrażają myśli i uczucia człowieka współczesnego, świadka wydarzeń, które budzą ustawiczny niepokój”. Dwaj animatorzy z komunistycznego kraju powiedzieli zachodnim widzom, że przyszłość nie rysuje się w jasnych barwach.

Jak na ironię, nagrodzony został film sprzeczny z duchem wystaw Expo. „ «Expo»to świat, który zaspokaja potrzeby człowieka, świat przychylny mu, poprawiony podług jego marzeń, marzeń niejednokrotnie trudnych do sformułowania [...] śledząc kolejne wielkie «Expo» poznajemy marzenia ludzkości”[23] - pisali Anna Piotrowska i Andrzej Osęka. Zwrócili też uwagę na to, że w mitologii Expo nie ma miejsca na problemy świata, nędzę i nieszczęścia, a jeżeli nawet, to tylko po to, by opowiedzieć budującą historię „wrażliwości moralnej człowieka”, który z tą nędzą walczy. Borowczyk i Lenica przestrzegają zaś przed automatyzacją ludzkich zachowań, mówią o dominacji technologii nad naturą, o lęku przed czymś strasznym i nieznanym. Opłakują świat, którego nie ma.

To, że przybyli z Europy Wschodniej, z pewnością pomogło im w dotarciu do zachodniej publiczności, która była ciekawa głosu zza żelaznej kurtyny. Komunistyczna Polska po wojnie, okupacji, Holokauście i epoce stalinowskiej mogła wydawać się równie odległa jak Mars. Każdy miał świadomość, ile nieszczęść przetoczyło się przez ten kraj, ale nikt nie wiedział, jak doświadczenia te wpłynęły na język awangardy artystycznej. Jeden $\mathrm{z}$ belgijskich filmowców

[18] C. de Givray, Bruxelles 58: c'est l'expérience qui manqué le plus au film expérimental, „Arts”, 30 kwietnia 1958.

[19] Severe perspectives, „Sight and Sound” 1992, vol. 1, no. 11, s. 31.

[20] J. Gerhard, Sukces polskich filmów...

[21] J. Płażewski, Poszukiwania na celuloidowej taśmie, „Przegląd Kulturalny” 1958, nr 20, s. 7.

[22] R. Onckelinx, op.cit.

[23] A. Piotrowska, A. Osęka, Mitologia „Expo”, „Miesięcznik Literacki” 1968, nr 6, s. 31. 
powiedział Płażewskiemu po konkursie: „My, Belgowie, nigdy nie będziemy mieli ciekawej kinematografii; jesteśmy na to za wygodni i za bogaci”[24].

\section{Początek nowej szkoły}

Sukces Domu to właściwy początek polskiej szkoły animacji - jednego z najciekawszych zjawisk w europejskim kinie animowanym od końca lat pięćdziesiątych do początku osiemdziesiątych. Polska szkoła opierała się na dwóch filarach. Pierwszym jest forma: autorska i ambitna, czerpiąca z warsztatu sztuk plastycznych, zwłaszcza malarstwa i plakatu, grafiki użytkowej. Oparta na nietypowych technikach, często eksperymentalna. Drugi filar to tematyka: egzystencjalna, filozoficzna, diagnozująca ducha czasów, a podskórnie - politycznie zaangażowana, krytyczna wobec oficjalnego obrazu rzeczywistości. Filmy polskiej szkoły animacji często mają kompozycję przypowieści albo wizualnego rebusu. $Z$ reguły nie posługują się dialogiem, lecz bogatą symboliką, która w oczach widzów może uchodzić za odmianę mowy ezopowej. Polscy animatorzy pytają o miejsce człowieka w świecie, o mechanizmy władzy, sposoby zniewolenia. Tworzą satyryczny obraz zjawisk społecznych albo cywilizacyjnych przemian.

Dom spełnia wszystkie te warunki, a na dodatek doskonale sprawdza się w roli filmu-manifestu $\mathrm{z}$ numerem jeden. Pisały o nim redakcje prestiżowych pism branżowych na całym świecie. Jego autorzy udzielili wywiadów między innymi dla „Cahiers du cinéma” oraz „Image et son", wystąpili również w belgijskiej telewizji, gdzie krótko po otrzymaniu nagrody wyemi-

[24] J. Płażewski, Poszukiwania..., s. 7.

[25] „Głos Wybrzeża” 1958, nr 104, s. 1.

[26] Z. Krakowski, Grand Prix dla Polski, „Kierunki” 1958, nr 20, s. 7.

[27] J. Haker, op.cit.

[28] K. Reisz, op.cit., s. 234.

[29] P.J. [J. Płażewski], Polski film „Dom” nagrodzony wielka nagroda w Brukseli, „Trybuna Ludu” 1958, nr 119.

[30] Cyt. za: Na marginesie „Domu”, „Nowa

Kultura" 1958, nr 20. towano zwycięski film[25]. W Polsce stali się głównymi reprezentantami animacji autorskiej dla dorosłych, którą - z braku odpowiedniego terminu - nazywano początkowo filmem eksperymentalnym. Każda formacja artystyczna potrzebuje symbolicznego początku, charyzmatycznych liderów oraz uwagi międzynarodowej krytyki, która w tym wypadku krótko po konkursie w Brukseli dostrzegła nowe zjawisko na mapie kina artystycznego.

" "Szkoła polska», bo tak chyba wolno powiedzieć, ukazała nowe i szczęśliwe rozwiązania stylowe, w których abstrakcja i deformacja rozbudowuje, podkreśla założenia ideowe i emocjonalne treści w filmie" [26] - pisał Z. Krakowski. Jonathan Haker odkrył w Brukseli „polską szkołę awangardy", która nie tylko ujawnia życie w swoim kraju, ale również otwiera się na dyskusję [27]. Karel Reisz pisał zaś o „warszawskiej szkole filmowej”, zwracając uwagę na kulturę produkcji oraz źródła finansowania. „Prawie wszystkie ważne filmy z Brukseli zostały zrobione przez zawodowców zbierających do kupy biedne budżety z resztek produkcji komercyjnej. To ryzykancki, frustrujący świat, i nic dziwnego, że sukcesów jest tak niewiele"[28]. Wyjątkiem była dla niego „szkoła warszawska”, która dała dowody na to, że „prawdziwa jakość” wymaga „dobrej woli i rozsądnej organizacji”. A nade wszystko wsparcia.

Podobno wielu obserwatorów wyrażało niedowierzanie, że polskie filmy eksperymentalne zostały zrealizowane za państwowe pieniądze, w oficjalnym systemie komunistycznej kinematografii. „Fakt ten najskuteczniej ucinał nieufne indagacje, czy aby wypadkiem filmów takich nie robi się w Polsce... konspiracyjnie i czy na pewno każdy ma prawo je oglądać" [29] - pisał Jerzy Płażewski. „France-Observateur” donosił $\mathrm{z}$ kolei:

Polska staje się krajem, o którym marzą wszyscy początkujący filmowcy, krajem, w którym ani przedsiębiorcy, ani politycy nie narzucają niemądrych nakazów. I odmiennie niż u prawie wszystkich innych uczestników festiwalu widać u młodych polskich filmowców jasność widzenia, siłę moralną, która każe nam wiele się po nich spodziewać[30]. 
Fragment ten przedrukowała „Nowa Kultura”, aby podkreślić różnicę, która dzieli postępowy Wschód od zacofanego Zachodu.

Prawda była oczywiście bardziej złożona. Polska szkoła animacji swoje sukcesy faktycznie zawdzięczała sprzyjającemu systemowi produkcji i dystrybucji, w którym doceniano poziom artystyczny filmu i wspierano ambitne projekty, nie zważając na ich komercyjny potencjał. $\mathrm{Z}$ drugiej strony, Borowczyk i Lenica zrealizowali swoje filmy dzięki uporowi i protekcji przyjaciół. Państwowa kinematografia nie czekała na nich $\mathrm{z}$ otwartymi ramionami. Wprost przeciwnie. Zgoda na finansowanie filmów krótkich w ramach Zespołów Autorów Filmowych nie była jednomyślna, została wymuszona siłą autorytetu Jerzego Kawalerowicza, a Dom powstał na gruzach projektu odrzuconego, a zarazem bardziej ambitnego[31]. Lenica i Borowczyk również wzięli resztki ze stołu produkcji filmów pełnometrażowych. Tak naprawdę to sukcesy twórców kina eksperymentalnego (i animacji autorskiej) stały się kartą przetargową $\mathrm{w}$ walce o zmianę profilu produkcji w wytwórniach małych form filmowych, gdzie jeszcze w 1956 roku nie było miejsca dla artystów takich jak Lenica i Borowczyk.

Ale zagraniczni reżyserzy tego wszystkiego nie wiedzieli i zazdrościli kolegom z Polski. Len Lye, laureat drugiej nagrody, wykorzystał Grand Prix dla Domu jako pretekst, by powalczyć w Ameryce o wsparcie dla własnych filmów. Napisał listy do ważnych osobistości w kraju, w tym do prezydenta Eisenhowera. W biografii autora Free Radicals czytamy:

Lye podkreślał fakt, że kraje komunistyczne [...] mocno wsparły film jako sztukę. [...] lubił kończyć swoje listy prowokacyjną uwagą, że skoro tak trudno znaleźć mu fundusze na filmy eksperymentalne w Stanach Zjednoczonych, planuje szukać środków w krajach za żelazną kurtyną[32].

Dom odczytywany był z pomocą klucza historycznego - zarówno w Polsce, jak i za granicą. Z dzisiejszej perspektywy taka lektura wydaje się oczywista. Przywykliśmy do tego, że polskie filmy animowane z okresu PRL-u od- znaczają się poważnym tonem oraz rozrachunkową tematyką. Widzowie $\mathrm{z}$ lat pięćdziesiątych czuli się jednak zaskoczeni. W taki oto sposób kształtowała się tradycja polskiej szkoły animacji, która zerwała ze stereotypem zabawnej kreskówki, proponując w zamian film-rebus o znamionach filozoficznej przypowieści, mówiący o egzystencjalnych rozterkach człowieka połowy XX wieku.

Kazimierz Żórawski postawił Dom na jednej szali z filmami szkoły polskiej Andrzeja Wajdy, Andrzeja Munka czy Jerzego Kawalerowicza. Pisał, że jest to film o „Polakach żyjących na granicy dwu światów: zwalonej w gruzy przeszłości i opornie realizującej się nowoczesności. Jest sześcioczęściową opowieścią o Warszawie i człowieczych uczuciach Polaka tamtych lat [...]"[33]. Mistrzowie polskiej szkoły filmowej również brali na swe barki odpowiedzialność za rozliczenie koszmaru wojny i okupacji. Najważniejszy film tego nurtu, Popiół i diament (1958) Andrzeja Wajdy, miał premierę w tym samym roku co Dom.

I tu znowu obok gruzów, ruin i koszmaru figurowały kwiatki z kolorowej bibułki, stare grawiury, głowa fryzjerska jakby przeniesiona $\mathrm{z}$ zakładu przedwojennego. Zestawienie charakterystyczne dla Polaka - orzekli obserwatorzy. Czyż nie tak wyglądała zniszczona Warszawa?[34]

Tak pytał Zygmunt Kałużyński. Rozpadająca się głowa $z$ gipsu oraz sekwencja $z$ rozproszonymi fotografiami kojarzyły mu się z traumą wojny, po której zostały gruzy i niepozwalające zasnąć wspomnienia. W innym tekście Kałużyński zauważył: „Krytyka zagraniczna upatrywała tu «halucynacyjne marzenie o nie-

[31] Pisałem na ten temat w tekście Powrócić do kina wizualnego. Borowczyk i Lenica w Zespole Autorów Filmowych „Kadr”, „Kwartalnik Filmowy" 2019, nr 105-106.

[32] R. Horrocks, Len Lye: A Biography, Auckland 20oo, s. 268.

[33] K. Żórawski, „Studio” 1973, nr 9; cyt. za: Lenica $w$ „Kwancie” [katalog], Warszawa 1973, s. 96. [34] Z. Kałużyński, Narodziny telewizji z ducha plastyki, „Miesięcznik Literacki” 1968, nr 11, s. 59. 
dostępnym domu» u Polaków, dotkniętych katastrofami historycznymi" [35].

Krytycy zagraniczni z większą wnikliwością wczytywali się w metaforyczne sceny. Nie musieli bowiem obawiać się cenzury. „Choć groźna postać w czerwieni może przywoływać Rosję, komunizm lub jedno i drugie [...], symbolika jest prawdopodobnie bardziej złożona, ponieważ czerwony i biały tworzą razem polskie barwy narodowe [...]"[36] - napisał dwadzieścia lat po premierze Raymond Durgnat o scenie z walczącymi szermierzami pożyczonymi od Mareya. Jego zdaniem sekwencja ta ukazuje konflikt z Wielkim Bratem albo wojnę polsko-polską w społeczeństwie, któremu siłą narzucono ustrój komunistyczny. Mimo iż Lenica i Borowczyk nie zgodziliby się z taką interpretacją (w scenariuszu mowa o „postaci człowieka Żółtego” i „Białego”[37]), wieloznaczne filmy polskiej szkoły animacji w przyszłości będą zachęcać do szukania politycznych aluzji głęboko poukrywanych pod powierzchnią obrazów. Podręcznikowym przykładem jest film Czerwone i czarne (1964) Witolda Giersza o walce toreadora (kolor czerwony) i byka (kolor czarny), odbierany za granicą - i również wbrew woli autora - jako opowieść o konflikcie Kościoła z PZPR[38].

[35] Idem, Film rysunkowy ratuje „szkołę polską, „Polityka” 1961, nr 2.

[36] R. Durgnat, Borowczyk and the cartoon renaissance, „Film Comment” 1976, vol. 12, no. 1.

[37] W. Borowczyk, J. Lenica, Scenariusz obrazowy filmu „Dom” (tytut tymczasowy „Miasto”), maszynopis, k. 2, Archiwum Filmoteki Narodowej - Instytutu Audiowizualnego, sygn. S-32126.

[38] Tak powiedział mi Witold Giersz w prywatnej rozmowie.

[39] W. Herrmann, Festival der Outsider, „Telegraf", 4 maja 1958.

[40] Zob. na przykład: W. Moritz, Narrative Strategies for Resistance and Protest in Eastern European Animation, [w:] A Reader in Animation Studies, ed. by J. Pilling, London, Paris, Rome, Sidney 1997, s. 39.

[41] W. Borowczyk, Co myśle, patrzac na rozebrana Polke, Warszawa 2007, s. 33.
Nie było to zresztą jedyna próba odczytania Domu jako szczerego głosu z Europy Wschodniej. Niemiecki dziennikarz Wilhelm Herrmann pisał w sprawozdaniu z konkursu w Brukseli: „Surrealistyczny polski film Dom zawiera aspekt polityczny. Względna wolność polityczna w tym kraju zdaje się rozszerzać w filmie do nieskończoności; Polska była także jedynym krajem bloku wschodniego, który wziął udział w konkursie"[39]. Jego zdaniem Dom to azyl dla zniewolonego umysłu, którego nie krępują żadne ograniczenia.

Po latach utrwali się legenda filmu jako dzieła opozycyjnego, wyrażającego protest wobec systemu nie tylko poprzez treść, lecz również swoją radykalną formę. William Moritz postawi Dom obok filmów kanonicznych dla historii kina: Ręki (Ruka, 1965) Jiřego Trnki, Bajki nad bajkami (Skazka skazok, 1979), Jurija Norsteina oraz Pikniku na trawie (Eine Murul, 1987) Priita Pärna[40]. Przyjmując tę perspektywę, można uznać, że film Borowczyka i Lenicy nie tylko rozpoczyna tradycję polskiej szkoły animacji, ale również otwiera peleton filmów-symboli, które zbudowały tożsamość artystycznej animacji Europy Wschodniej i Centralnej.

\section{Trudny powrót do Polski}

Pieniądze budziły największe emocje. Borowczyk i Lenica otrzymali nagrodę w wysokości 10 tys. dolarów. „Przeliczano tę sumę w polskich gazetach na wszystkie waluty globu, polski świat artystyczny opanowała psychoza łatwego wzbogacenia się. "Zachód» dla Polaków stał się synonimem bajecznej odkrywkowej kopalni złota"[41] - wspominał po latach Borowczyk.

Nie tak łatwo ocenić realną wartość 10 tys. dolarów, jako że amerykańska waluta funkcjonowała zarówno w oficjalnym przeliczniku, jak i w szarej strefie handlu i usług. W 1957 roku czarnorynkowa cena dolara skoczyła do 200220 zł, potem zaczęła spadać, by pod koniec dekady osiągnąć pułap około 90 zł. Turyści otrzymywali dolara po oficjalnym kursie 24 zł. „Krajowców dewizowych” rozliczano po korzystniejszym kursie 72 zł za dolara lub za- 
mieniano walutę na czeki dolarowe $\mathrm{PKO}$ [42]. Według kalkulatora inflacji to równowartość ok. 88 tys. dzisiejszych dolarów, jednak siła nabywcza amerykańskiej waluty w zrujnowanej wojną Polsce socjalistycznej była znacznie większa. Dolar pozwalał kupić towary w ogóle niedostępne za złotówki oraz umożliwiał podróże zagraniczne, które uchodziły za luksus przewyższający jakiekolwiek dobra materialne. Zaokrąglając, Borowczyk i Lenica otrzymali nie tylko równowartość ok. miliona zł (po cenie czarnorynkowej) lub 700 tys. zł (po kursie oficjalnym), ale także swego rodzaju paszport, który ułatwiał planowanie życia na Zachodzie. Dla porównania, w 1958 roku przeciętna płaca netto w Polsce wynosiła tylko 1331 zł; kilogram chleba żytniego kosztował 3 zł, kilogram kiełbasy - $26 \mathrm{zl}$, cukru - $12 \mathrm{zl}$, półbuty - $330 \mathrm{zl}$, a płaszcz męski wełniany - 826 zł[43]. Krótko mówiąc: wygrali fortunę.

To właśnie nagroda pieniężna zbudowała rangę konkursu w Brukseli. „W ustroju kapitalistycznym, w warunkach fundowania nagrody przez prywatną instytucję - za byle co takiej nagrody nie dają” [44] - donosił „Express Ilustrowany".

Pieniądze okazały się jednak sporym problemem. Rodziły dylematy: wracać, zostać? 26 maja 1958 roku, miesiąc po Brukseli, Lenica pisał z Paryża do Tadeusza Konwickiego: „zastanawiam się, co z tym fantem zrobić. Bardzo mnie to martwi i męczę się nad podjęciem jakiejkolwiek decyzji. Starczyłoby na spokojne życie tutaj przez rok albo i dwa - z drugiej strony ciągle wydaje mi się, że mimo wszystko w kraju są większe możliwości”[45]. Bał się, że po powrocie „kochani filmowcy zagrý́liby”, co oznacza, że nie będzie mógł już pracować $\mathrm{w}$ animacji, gdyż zawistne środowisko filmowe nie da mu spokoju.

Otrzymali kilka propozycji od zachodnich firm. Widmo kariery zagranicznej zaczęło majaczyć na horyzoncie. Borowczyk: „zgłosiło się do mnie kilkunastu producentów, których kultura filmowa i środki finansowe skłoniły do przedstawienia mi propozycji. Byli to Amerykanie, Niemcy, Włosi i Francuzi"[46].
Dostał ofertę poprowadzenia szkoły i studia animacji w Izraelu. Podpisał pięcioletni kontrakt z Le Cinéastes Associés we Francji, dzięki któremu mógł „realizować filmy krótkometrażowe i długometrażowe w zupełnej swobodzie, według własnych scenariuszy" dla Jacques'a Forgeota. Lenica i Borowczyk nawiązali również współpracę $\mathrm{z}$ charyzmatycznym producentem Anatolem Daumanem z Argos Film, dla którego każdy z nich - ale już osobno - zrealizował w 1959 roku swój pierwszy film na Zachodzie.

Zapewne już wtedy, w Brukseli, zapadła decyzja o emigracji. Musieli jednak od razu wracać do domu. Z akt paszportowych wynika, że otrzymali zgodę wyłącznie na pięciodniowy pobyt w Belgii[47]. Decyzja o pozostaniu na Zachodzie pogrzebałaby dystrybucję Domu, poskutkowała oskarżeniem o zdradę narodową. Obaj artyści nigdy zresztą nie zdecydowali się na pełną emigrację, zawsze podkreślali, że są polskimi twórcami pracującymi za granicą. Nie zrzekli się polskiego obywatelstwa. Podjęli starania o uzyskanie tak zwanego paszportu konsularnego, który pozwalał bez przeszkód przekraczać granicę w jedną i drugą stronę.

Sukces w Brukseli pokrzyżował wcześniejsze plany. Po powrocie do Polski Lenica - nie czekając na wypłatę nagrody - od razu rozpoczął przygotowania do wyjazdu do Francji, gdzie zamierzał z żoną spędzić trochę czasu, popracować, być może nakręcić film. Borowczyk zaś skupił się na realizacji swojego pierw-

[42] J. Kochanowski, Tylnymi drzwiami. Czarny rynek w Polsce 1944-1989, Warszawa 2016 (e-book).

[43] Mały Rocznik Statystyczny 1959, Warszawa 1959, s. 92-93, 108.

[44] Cudze chwalicie..., „Express Ilustrowany” 1958, nr 108.

[45] J. Lenica, Labirynt, oprac. E. Czerwiakowska i T. Kujawski, Poznań 2002, s. 108.

[46] W. Borowczyk, op.cit., s. 113. Następny cytat - s. 112.

[47] Notatka służbowa dot. wyjazdów służbowych ob. Jana Lenicy, 23.09.1966, k. 1, Archiwum Instytutu Pamięci Narodowej, sygn. 728/68028. 
szego w pełni autorskiego projektu dla Studia Miniatur Filmowych w Warszawie, gdzie zresztą obaj zostali zatrudnieni na stanowisku reżyserów i gdzie planowali kręcić filmy jako Zespół KINO. Podjęte w Brukseli zobowiązania także Borowczyka skierowały na nowe tory. Wiedział, że kolejny film zrealizuje we Francji dla Anatole’a Daumana.

Rozliczenie nagrody sprawiło duże problemy. Lenica i Borowczyk chcieli otrzymać pełną sumę w dolarach. Władze robiły zaś wszystko, aby do tego nie dopuścić. W PRL-u ustawicznie brakowało amerykańskiej waluty, toteż filmowcom zaproponowano złotówki po oficjalnym kursie. Z pomocą znajomych szukali protekcji, by cofnąć tę decyzję. Pisali listy do prominentnych polityków, w tym do premiera Cyrankiewicza. „Z pieniędzmi niedobrze - odpowiedź na nasze pismo jest odmowna, obawiam się, że $z$ tego nic nie będzie" [48] - pisał Jan Lenica do Teresy Byszewskiej w lipcu 1958 roku. Zagrozili, że w takim wypadku odmówią przyjęcia nagrody, co poskutkowałoby skandalem dyplomatycznym, który zburzyłby z takim trudem zbudowany wizerunek postępowej kinematografii bloku wschodniego. Daniel Szczechura pamięta, że ostatecznie poszli na kompromis: połowę kwoty odebrali w dolarach, a połowę w złotówkach [49].

Przez kilka miesięcy duet działał w zawieszeniu. W 1959 roku Borowczyk i Lenica

[48] List J. Lenicy do T. Byszewskiej, 17.07.1958, Archiwum Jana Lenicy, Muzeum Narodowe w Poznaniu.

[49] Daniel Szczechura opowiedział mi tę historię na konferencji w trakcie festiwalu Animator (Poznań, 7.07.2018), jako dopisek do mojego wystąpienia o brukselskiej przygodzie Lenicy i Borowczyka.

[50] „Dom” na ekranie, „Trybuna Ludu” 1958, nr 130. Film wyświetlano w kinach „Przyjaźñ” i „Młoda Gwardia”.

[51] „Filmowy Serwis Prasowy” 1958, nr 6/68. [52] Opinie redaktora, „Dookoła Świata” 1958, nr 247.

[53] Opinie czytelników, „Dookoła Świata” 1958, nr 245 . udzielali jeszcze razem wywiadów, choć wiadomo było, że nie planują wspólnych filmów. Tymczasem Dom trafił do szerokiej dystrybucji w polskich kinach.

\section{Nad Domem błyska i grzmi}

Film Borowczyka i Lenicy został sparowany z włoską komedią Bigamista (Il bigamo, reż. Luciano Emmer, 1956) i oddany do rozpowszechniania $\mathrm{w}$ formie krótkiego dodatku do seansu pełnometrażowego (od 10 maja 1958 roku)[50]. Dzięki temu możemy oszacować - niestety, tylko w przybliżeniu - skalę oddziaływania Domu po sukcesie w Brukseli. Bigamista cieszył się bowiem sporą popularnością. Wiemy, że w Warszawie zajął piąte miejsce w miesięcznym box offisie, przyciągając przed ekrany 47524 osób[51]. To oznacza, że eksperymentalny, adresowany do garstki wyrobionych widzów Dom widział przynajmniej co dwudziesty mieszkaniec stolicy.

Film od razu wzbudził kontrowersje. I wywołał konsternację. Nagroda zaostrzyła apetyt: spodziewano się dzieła porywającego i widowiskowego, które pozwoli poczuć dumę z polskiej kinematografii. Wejdźmy teraz w skórę widza, który przyszedł na komedię z Marcello Mastroiannim i przez dziesięć minut męczył się na dodatku, który atakował obrazami żarłocznej peruki i rozpadającej się głowy fryzjerskiej, a także kaskadą dźwięków z innego wymiaru. Publiczność wielokrotnie gwizdami i tupaniem domagała się przerwania projekcji[52]. „Wydaje mi się, że zainteresowane czynniki powinny przed wyświetleniem tego filmu zastanowić się, czy nie za wcześnie jeszcze na pokazywanie abstrakcyjnej sztuki w takiej ilości tysiącom nie zawsze przygotowanych do tego widzów"[53] - pisał w poetyce donosu czytelnik „Dookoła Świata”, sugerując, że lepszym pomysłem byłaby dystrybucja ograniczona do klubów filmowych $\mathrm{z}$ ambitnym repertuarem albo nawet na specjalnych pokazach. Polska jest bowiem niegotowa na awangardę.

Zdezorientowani widzowie wybuchali śmiechem w najmniej stosownych momentach, gdyż byli przyzwyczajeni do tego, że film animowany 
to synonim komedii[54]. Panowało powszechne przekonanie, że nagroda $\mathrm{w}$ Brukseli nie daje prawa do szerokiej dystrybucji filmu, a nadgorliwość urzędników, który chcieli się pochwalić sukcesem, doprowadziła do nieporozumień. „Tak, tak, nie zawsze snobizm jest udziałem mas, częściej elity - nie wyłączając czasem jurorów, co nagrody przyznają" [55] - pisał widz do redakcji „Zielonego Sztandaru”.

W wywiadzie dla „Image et son” Borowczyk i Lenica zapewnili, że taki odbiór filmu był przez nich z góry przewidziany:

Projekcjom Domu często towarzyszyły następujące doświadczenia: podczas wyświetlania widzowie są zmrożeni. Po zakończeniu filmu odbiór jest już niekorzystny - pohukiwanie i gwizdy. Zawsze źle rozumieliśmy to zjawisko, ponieważ nie można zaprzeczyć, że film wzbudza duże zainteresowanie w trakcie projekcji. Być może widownia była zszokowana, widząc realistyczne obrazy bez konwencjonalnych związków między nimi, do których przywykła[56].

Skandal mógł być wręcz wkalkulowany w strukturę Domu. Buczenie w trakcie ogłaszania werdyktu również okazało się właściwą oprawą. Lecz to oznacza, że gdyby film nie dostał nagrody, prawdopodobnie nie trafiłby do dystrybucji, a w zamian rozpocząłby się - co zresztą sugerował Borowczyk - rytuał szukania winnych, którzy zezwolili na jego produkcję[57].

Reakcje krytyki były per saldo nieprzychylne. Nawet ci publicyści, którzy interesowali się filmem animowanym i z radością obserwowali jego renesans, na Dom zareagowali wrogo. "Zadziwił mnie on poziomem technicznym i wynalazczością autorów, lecz jako całość zawiódł, nie podobał mi się" [58] - utyskiwał Lech Pijanowski. Nie dostrzegł artystycznego celu w tym „nadto zawiłym i hermetycznym” filmie. Tadeusz Kowalski, wielbiciel talentu Lenicy i Borowczyka, pisał zaś: „Wzbudza osobliwe i mieszane uczucia. Jest zdumiewająco pomysłowy w zakresie formalnym, ale konstrukcja jego nasuwa poważne wątpliwości”[59]. W trakcie całego seansu szukał metafory, wokół której mógłby zbudować interpretację, ale jej nie znalazł. Pochwalił więc grafikę, która jest „na wskroś nowoczesna” i „najwyższej klasy”.

Brak pomysłu na film i poczucie zmęczenia wraca jak refren $w$ recenzjach i omówieniach. Ryszard Wojna skrytykował Dom za „nieprzyjemne dążenie do «intelektualizowania», chwilami sztuczne i banalne", a także za „brak prawdziwego zainteresowania człowiekiem" [60]. W słowach tych czuć już ducha zbliżającej się Uchwały Sekretariatu KC w sprawie kinematografii. Ryszard Lassota zdradził z kolei, że film Borowczyka i Lenicy wywołał konflikt w środowisku krytyków. Z jednej strony płynęły pochwały i gratulację za Grand Prix w Brukseli, a z drugiej - fale krytyki i malkontenctwa. Ale jak sam zaznaczył, niełatwo było wcielić się w obrońcę tego "dziwnego i drażniącego" filmu[61]. Lassota przeczuwał, że to manifest mówiący o walce różnych estetyk, ale również nie uchwycił idei przewodniej.

Stanisław Dygat zwrócił uwagę, że po pierwszej fali zachwytu Lenica i Borowczyk nie urośli w oczach krytyków, ale na odwrót, zmalała ranga nagrody w Brukseli: „gdy wielką nagrodę brukselską otrzymuje szwagier Tadzia Konwickiego, staje się ona czymś równoznacznym [...] $\mathrm{z}$ budzikiem lub wiankiem kiełbasy zdobytym na namydlonym słupie w czasie festynu w Koninie" [62]. A ponieważ nikt nie potrafił przeliczyć, jaka jest realna wartość 10 tys. dolarów wobec

[54] (lcz), Śmiech dowodem niezrozumienia, „Życie Radomskie” 1958, nr 203.

[55] Nie tak, nie tak - Redaktorze!, „Zielony

Sztandar" 1958, nr 70 .

[56] Entretien avec W. Borowczyk et Jan Lenica, „Image et son” 1960-1961, no. 136/137, s. 24.

[57] W. Borowczyk, Szanowny Panie Redaktorze!, „Film” 1964, nr 35, s. 11.

[58] L. Pijanowski, Droga eksperymentu filmowego, „Świat” 1958, nr 19.

[59] T. Kowalski, Dom, czyli poszukiwanie uniwersalnej formutki, „Film” 1958, nr 23, s. 5. [60] R. Wojna, Udany czy nieudany, „Ekran” 1958, nr 23, s. 3.

[61] R. Lassota, Co poeta chciał przez to powiedzieć, „Ekran” 1958, nr 27, s. 7.

[62] S. Dygat, Rozmyślania przy goleniu, „Przegląd Kulturalny" 1958, nr 19. 
złotego, zaczęto zastanawiać się, czy to aby faktycznie tak dużo. „Stwierdzono wreszcie, że właściwie to gruba przesada i nie ma tam znowu czego zazdrościć, bo w końcu wypada to akurat tyle, co główna wygrana w Totka-Lotka. A więc absolutnie każdy przeciętny obywatel wart jest potencjalnie tyle co Borowczyk i Lenica”.

Film miał jednak swoich gorliwych obronców. Niektórych już przywołałem. Jak na ironię, zawodowi recenzenci, rozeznani w światowej animacji, trudzili się niekiedy nad złamaniem zaszyfrowanego przekazu, ponosząc klęskę, a publicyści na pozór nieprzygotowani do odbioru awangardowego kina - bez trudu odczytywali intencje twórców. Stawiali Dom na jednej szali ze szkołą polską, poddawali się sile obrazów strasznych, lecz przejmujących. I wychodzili z kina bez poczucia, że ktoś z nich zadrwił.

Na przekór malkontentom, którzy utyskiwali na nieczytelną kompozycję filmu, Stanisław Grzelecki pisał, że w roku 1958 konwencjonalna fabuła nie jest w stanie wyrazić niepokojów człowieka współczesnego. Dlatego twórcy Domu posłużyli się ciągiem obrazów i skojarzeń[63].

„ «Dom» Borowczyka i Lenicy męczy jeszcze przez cały wieczór. Ba, nazajutrz jeszcze przypomni się wam swym nastrojem twórczego niepokoju" [64] - pisał z kolei dziennikarz „Kuriera Polskiego”. Słusznie zauważył, że każdy widz musi odczytać ten egzystencjalny film po swojemu. Bolesław Michałek również zrozumiał intencje reżyserów: „To nie jest krzyżówka, którą się rozwiązuje z nudów, tylko utwór bezkompromisowy, dość rzadki we współczesnym kinie; dzieło, którego zadaniem nie jest objaśniać, lecz odkrywać otaczający świat”[65]. Stanął w obronie nie tylko Borowczyka i Lenicy, ale całej formacji, która dopiero wyłaniała się na

[63] S. Grzelecki, Nad domem błyska i grzmi, „Przegląd Kulturalny” 1958, nr 26, s. 2.

[64] Z. Wawrzyniak, „Dom” pełen niepokoju, „Kurier Polski” 1958, nr 113.

[65] B. Michałek, Cwaniacy, „Nowa Kultura” 1958, nr 28.

[66] List W. Borowczyka do J. Lenicy, 8.07.1962, Cinématheque Française, zbiory Waleriana Borowczyka. horyzoncie. „W pewnych kołach panuje przekonanie, że nasze filmy eksperymentalne - to przysłowiowe «nabieranie gości», jeszcze jeden sposób wyłudzania pieniędzy od państwa przez artystycznych cwaniaków". W rzeczywistości to od takich „cwaniaków” zależy przyszłość kina.

Kilka lat później nie pamiętano już o kontrowersjach związanych z wyświetlaniem Domu. Nie cytowano negatywnych recenzji. Zaczęto utrwalać legendę wielkiego sukcesu, który odmienił polską animację autorską. Głosy malkontentów nie zaszkodziły również karierze Borowczyka i Lenicy. Grand Prix w Brukseli ułatwiło robienie kariery na Zachodzie, ale jednocześnie - istnieją przesłanki, by tak myśleć - stało się kością niezgody. W 1962 roku Borowczyk napisał do Lenicy oskarżycielski list, w którym zarzucił mu, że nie ma nic wspólnego z filmami zrealizowanymi w Polsce, a jego „dopisane” współautorstwo było smutną koniecznością w uzyskaniu protekcji kierownictwa „Kadru”. „Potwierdziłeś to sam w Brukseli w 1958 roku” kończy argumentację Borowczyk[66]. Mimo iż list ten w żaden sposób nie rozstrzyga sporu o autorstwo Domu (w żadnym duecie kompetencje i nakład pracy nie rozkładają się po równo), pozwala wysnuć taki oto wniosek: nagroda stworzyła problem, który przed wyjazdem na konkurs prawdopodobnie nie istniał. W Brukseli okazało się, że ta szalona, z początku amatorska i na wskroś eksperymentalna działalność filmowa, realizowana w przyjacielskiej atmosferze na marginesie pracy zawodowej, to w rzeczywistości poważna praktyka artystyczna, przynosząca zarówno zysk materialny, jak i uznanie w oczach światowej krytyki, która dwóch młodych plastyków z Warszawy w jeden wieczór nobilitowała na młodych gniewnych europejskiej awangardy. Z tą świadomością nie dało się dłużej dzielić uznaniem.

Wbrew wcześniejszym zapewnieniom Lenica i Borowczyk nie nakręcili już wspólnie żadnego filmu ani nie rozpoczęli działalności jako Zespół KINO. Mimo to ich złączone nazwiska stały się synonimem przemian w filmie animowanym Europy Środkowej. W wymiarze symbolicznym - na zawsze pozostali duetem. 
B I B L I O G R A F I A

Borowczyk W., Co myślę, patrząc na rozebraną Polkę, Warszawa 2007

Borowczyk W., Szanowny Panie Redaktorze!, „Film” 1964, nr 35

Cudze chwalicie..., „Express Ilustrowany” 1958, nr 108

„Dom” na ekranie, „Trybuna Ludu” 1958, nr 130

Durgnat R., Borowczyk and the Cartoon Renaissance, „Film Comment” 1976, vol. 12, nr 1

Dygat S., Rozmyślania przy goleniu, „Przegląd Kulturalny" 1958, nr 19.

Entretien avec W. Borowczyk et Jan Lenica, „Image et son" 1960-1961, nr 136/137

„Filmowy Serwis Prasowy” 1958, nr 6/68

Gerhard J., Po międzynarodowym Konkursie Filmów Eksperymentalnych, „Wiadomości Filmowe” 1958, nr 22

Gerhard J., Sukces polskich filmów eksperymentalnych w Brukseli, „Przekrój” 1958, nr 685

Gerhard J., Walerian Borowczyk i Jan Lenica po sukcesie "Domu” w Międzynarodowym Konkursie Filmów Eksperymentalnych, „Wiadomości Filmowe” 1958, nr 23

[Gerhard J.] (G), Siedem filmów polskich zakwalifikowanych do konkursu, „Wiadomości Filmowe” 1958, nr 20

Givray C. de, Bruxelles 58: c'est l'expérience qui manqué le plus au film expérimental, „Arts”, 30 kwietnia 1958

Grzelecki S., Nad domem błyska i grzmi, „Przegląd Kulturalny" 1958, nr 26

Haker J., Two Men and a Wardrobe, „Film Quarterly”, Spring 1959, vol. 12, nr 3

Hendrykowski M., Dwaj ludzie z szafą. Historia pewnej etiudy, Poznań 2015

Herrmann W., Festival der Outsider, „Telegraf”, 4 maja 1958

Horrocks R., Len Lye: A Biography, Auckland 2000

Jacobs L., Morning for the Experimental Film, „Film Culture" 1959, nr 19

Kałużyński Z., Film rysunkowy ratuje „szkołę polską, „Polityka” 1961, nr 2

Kałużyński Z., Narodziny telewizji z ducha plastyki, „Miesięcznik Literacki” 1968, nr 11

Kochanowski J., Tylnymi drzwiami. Czarny rynek w Polsce 1944-1989, Warszawa 2016

Kowalski T., Dom, czyli poszukiwanie uniwersalnej formułki, „Film” 1958, nr 23

Krakowski Z., Grand Prix dla Polski, „Kierunki” 1958, nr 20, s. 7

Lassota R., Co poeta chciał przez to powiedzieć, „Ekran” 1958, nr 27

(lcz), Śmiech dowodem niezrozumienia, „Życie Radomskie" 1958, nr 203
Le film polonais DOM remporte le Premier Grand Prix de la Compétition Internationale du Film Expérimental, „La nouvelle gazette”, 30 kwietnia 1958

Lenica J., Labirynt, oprac. E. Czerwiakowska i T. Kujawski, Poznań 2002

Lenica $w$ „Kwancie” [katalog], Warszawa 1973

M.J., Soirée de clôture de la compétition internationale en film expérimental, „La derniere heure”, 29 kwietnia 1958

Mały Rocznik Statystyczny 1959, Warszawa 1959

Michałek B., Cwaniacy, „Nowa Kultura” 1958, nr 28

Moritz W., Narrative Strategies for Resistance and Protest in Eastern European Animation, [w:] A Reader in Animation Studies, ed. by J. Pilling, London-Paris-Rome-Sidney 1997

Na marginesie „Domu”, „Nowa Kultura” 1958, nr 20

Nie tak, nie tak-Redaktorze!, „Zielony Sztandar” 1958, nr 70

Onckelinx R., Days of Experiment, „Films and Filming”, June 1958

Opinie czytelników, „Dookoła Świata” 1958, nr 245

Opinie redaktora, „Dookoła Świata” 1958, nr 247

Pijanowski L., Droga eksperymentu filmowego, „Świat” 1958, nr 19

Piotrowska A., Osęka A., Mitologia „Expo”, „Miesięcznik Literacki” 1968, nr 6

Płażewski J., Grand Prix w Brukseli, „Życie Warszawy” 1958, nr 102

Płażewski J., Poszukiwania na celuloidowej taśmie, „Przegląd Kulturalny” 1958, nr 20

[Płażewski J.] P.J., Polski film „Dom” nagrodzony wielka nagroda w Brukseli, „Trybuna Ludu” 1958, nr 119

Reisz K., Experiment at Brussels, „Sight and Sound” 1958, vol. 27, nr 5

Severe perspectives, „Sight and Sound” 1992, vol. 1, nr 11

Sitkiewicz P., Powrócić do kina wizualnego. Borowczyk i Lenica $w$ Zespole Autorów Filmowych „Kadr”, „Kwartalnik Filmowy” 2019, nr 105-106

Sukces polskich filmów eksperymentalnych na konkursie w Brukseli, „Trybuna Ludu” 1958, nr 113

Tyler P., New Images, „Film Quarterly”, Spring 1959, vol. 12, nr 3

Wawrzyniak Z., „Dom” pełen niepokoju, „Kurier Polski” 1958, nr 113

Wojna R., Udany czy nieudany, „Ekran” 1958, nr 23

\section{Z B I O R Y D O K U M E T Ó W}

Archiwum Filmoteki Narodowej - Instytutu Audiowizualnego

Archiwum Instytutu Pamięci Narodowej

Archiwum Jana Lenicy, Muzeum Narodowe w Poznaniu

Cinématheque Française, zbiory Waleriana Borowczyka 